\title{
ERRATUM
}

\section{Magnetic resonance-guided focused ultrasound thalamotomy for essential tremor: a 5-year single-center experience}

TO THE READERSHIP: An error appeared in the article by Sinai et al. (Sinai A, Nassar M, Eran A, et al. Magnetic resonance-guided focused ultrasound thalamotomy for essential tremor: a 5-year single-center experience [published online July 5, 2019]. J Neurosurg. doi:10.3171/2019.3.JNS19466).

In the Assessments section of the Methods, the Clinical Rating Scale for Tremor (CRST) was incorrectly stated as ranging from " $0-152$ points." The correct range for the CRST score is $0-160$ points. The updated sentence appears below.

Tremor was assessed using the Clinical Rating Scale for Tremor (CRST) score (ranging from 0-160 points, higher scores indicating greater disability).

The article has been corrected online as of February 14, 2020.

Ilana Schlesinger, MD

Rambam Health Care Campus, Haifa, Israel

CORRESPONDING ARTICLE See pp 417-424.

INCLUDE WHEN CITING

Published online February 14, 2020; DOI: 10.3171/2020.1.JNS19466a.

CAANS 2020, except where prohibited by US copyright law 